\title{
Effects of addition of nutritionally improved straw in dairy cow diets at 2 starch levels
}

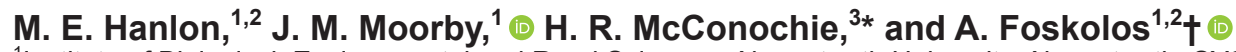 \\ ${ }^{1}$ Institute of Biological, Environmental and Rural Sciences, Aberystwyth University, Aberystwyth, SY23 3EE, United Kingdom \\ ${ }^{2}$ Department of Animal Sciences, University of Thessaly, Larisa, 411 10, Greece \\ ${ }^{3}$ Wynnstay Group Plc, Llansantffraid, SY22 6AQ, United Kingdom
}

\begin{abstract}
The objective of this experiment was to explore the effects of different dietary neutral detergent fiber sources within diets of high-producing dairy cattle with low or high starch concentrations on milk yield and composition, dry matter intake (DMI), total-tract digestibility, nitrogen $(\mathrm{N})$ partitioning, and rumen function and health. Holstein-Friesian cows in early- to mid-lactation $(\mathrm{n}=12 ; 666 \pm 67 \mathrm{~kg}$ of body weight at the start of the experiment) and dry cannulated Holstein-Frisian cows $(\mathrm{n}=4 ; 878 \pm 67 \mathrm{~kg}$ of body weight at the start of the experiment) were used in multiple $4 \times 4$ Latin square design experiment and were offered 4 different diets. The treatments were 50:50 forage-to-concentrate diets within a total mixed ration (TMR) consisting, on a dry matter (DM) basis, of $42.4 \%$ grass silage as the main forage, $7.6 \%$ chopped untreated wheat straw, or sodium hydroxide $(\mathrm{NaOH})$ wheat straw pellets, known as nutritionally improved straw (NIS), and $50.0 \%$ of 1 of 2 different concentrates with low or high starch level (TMR starch level of 16.0 vs. $24.0 \%$ of DM, respectively). Four experimental periods were used, each consisting of a 21-d adaptation period and $7 \mathrm{~d}$ of sampling. Dry matter intake and milk yield were both affected by the type of straw included in the diet. A 1.6 $\mathrm{kg} / \mathrm{d}$ higher DMI was seen when NIS was fed compared with untreated straw, resulting in a $1.7 \mathrm{~kg} / \mathrm{d}$ higher milk yield. Milk protein concentration was affected by straw type and starch level, and it was 4 and $3 \%$ higher when NIS and high-starch diets were fed, respectively. Diets with NIS were more positively effective when fed with low levels of starch. These results illustrate that feeding NIS to high-producing lactating dairy cows fed low or high starch concentrations has a positive effect on performance.
\end{abstract}

\footnotetext{
Received February 13, 2020.

Accepted July 4, 2020.

*Current affiliation: Zinpro Corporation, Eden Prairie, MN.

†Corresponding author: afoskolos@uth.gr
}

Key words: neutral detergent fiber, nutritionally improved straw, starch

\section{INTRODUCTION}

High-producing dairy cattle have large nutritional demands to meet performance and production requirements during lactation. Increased concentrations of starch in their diets are typically supplied, to meet energy requirements (Boerman et al., 2015). The dietary starch content for a high-producing dairy cow diet averages 22 to $24 \%$ of ration DM (Duffield et al., 2008; Van Amburgh et al., 2015), yet the inclusion can vary based on the energy demands placed on the herd or cow and the animal's stage of lactation (Boerman et al., 2015; McCarthy et al., 2015). However, diets with large quantities of high-starch concentrates can potentially affect rumen health and function (Calsamiglia et al., 2012; Humer et al., 2018). Increased levels of rapidly fermentable starch in the diet can increase the production of VFA in the rumen beyond its absorption and buffering capacity, resulting in a reduced ruminal $\mathrm{pH}$ (Dijkstra et al., 2012). This can result in subacute ruminal acidosis (Plaizier et al., 2008) or depressed feed intake due to increased levels of propionic acid (Allen et al., 2009). In most cases higher dietary starch levels result in lower NDF levels (Hatew et al., 2015; Albornoz et al., 2019). Taking into account the importance on rumen health and function not only of physically effective fiber in the TMR (Humer et al., 2018) but also of the NDF content and its degradation rate (Dijkstra et al., 2012), it may be suggested that slowly degradable NDF may result in an optimal rumen balance to maintain a suitable and efficient rumen metabolism.

A common source of NDF used in lactating dairy cow diets in the UK is wheat straw (Moorby et al., 2006, 2009, 2016); however, compared with other forages, straws have a higher NDF content and slower degradation rate (Raffrenato et al., 2019), and this may reduce DMI. Indeed, a positive relationship between NDF sources with a faster degradation rate and DMI exists, due to the reduced physical fill in the rumen over time 
allowing a higher voluntary feed intake (Van Soest, 1994; Mertens, 2005). Past studies have reported that supplying lactating dairy cows with NDF sources that have been chemically treated with sodium hydroxide $(\mathrm{NaOH})$ resulted in increased DMI, milk yield (Canale et al., 1988), and milk protein and fat content, compared with untreated sources (Jami et al., 2014). Nutritionally improved straw (NIS) is also an $\mathrm{NaOH}$ chemically treated product that is made by chopping and grinding straw into a coarse meal and adding a small amount of $\mathrm{NaOH}$ (Sundown Products Ltd., Huntingdon, UK). Therefore, the objective of this study was to investigate the effects of NIS addition, compared with untreated straw, in diets with different starch levels on performance of dairy cows. We hypothesized that replacing untreated straw with NIS in the diets of lactating dairy cows, especially in those with a high starch concentration, would result in higher milk production, due to the inclusion of NIS in diets potentially improving fiber digestibility and, thus, rumen environment, allowing for maximized energy intake from high-starch diets, resulting in improved performance.

\section{MATERIALS AND METHODS}

\section{Animals and Experimental Design}

A multiple $4 \times 4$ Latin square experimental design was used to address the objective of the study. The study consisted of 2 trials (trial 1: lactation; trial 2: rumen function). Twelve mid-lactation Holstein cows from Aberystwyth University's Trawscoed Farm herd (averaging $114 \pm 19$ DIM and $666 \pm 67 \mathrm{~kg}$ BW; Aberystwyth, UK) were enrolled in the lactation trial, and 4 dry ruminally cannulated Holstein cows (averaging 878 $\pm 67 \mathrm{~kg} \mathrm{BW}$ ) were enrolled in the rumen function trial. Three squares were used for the lactation trial, and 2 of these were used for digestibility measurements. For the rumen trial, 1 square of cows was used; all experiments occurred simultaneously, so that the same feed could be offered to all animals on the same treatments. All cows underwent a 2-wk pre-adaptation period, housed in tiestalls, consisting of $1 \mathrm{wk}$ during which the required amounts of a compound concentrate feed composited from both experimental concentrates (50:50 on a DM basis) were gradually introduced into the diets, because cows were previously fed lower amounts of concentrate. The second week consisted of collection of milk yield, BW, and DMI measurements for the cows of trial 1. The lactation-trial cows were ranked and allocated in squares, based on individual milk yields (the top 4 highest yielders in Latin square 1 , next 4 in square 2 , and so on). Once assigned to a square, each cow was assigned a treatment at random. The trial consisted of 4 experi- mental periods, where each had a duration of $21 \mathrm{~d}$ for adaptation and $7 \mathrm{~d}$ for sample collection. Once each experimental period was completed, cows then began a new treatment directed by the Latin square design. The sequence of treatments was balanced for carryover effects, with each treatment preceded by every other treatment an equal number of times (Hinkelmann and Kempthorne, 2008). All cows were housed in tiestalls for the duration of the experiment.

A $2 \times 2$ factorial experimental design was used. The 2 factors investigated were as follows: (1) starch level at 16.0 versus $24.0 \%$ of DM, and (2) inclusion or noninclusion of NIS to replace untreated straw. This design resulted in the following 4 treatments: low starch + untreated straw (designated in tables as LSTR), low starch + NIS (LNIS), high starch + untreated straw (HSTR), and high starch + NIS (HNIS). The exact experimental diets were formulated (Table 1) using the Cornell Net Carbohydrate and Protein System (Van Amburgh et al., 2015). The NIS product comprised pelleted $\mathrm{NaOH}$-treated wheat straw, and the required amounts of NIS and untreated straw were obtained from the same source (Sundown Products Ltd.), to ensure similar initial chemical compositions. To facilitate mixing and to ensure homogeneity between experimental periods, the 2 concentrates were produced as a single batch of pellets at the beginning of the experiment (Wynnstay Ltd., Llansantffraid, UK). The 2 commercially produced concentrate pellets were prepared by grinding the constituent ingredients to pass through a screen with holes of $3.2-\mathrm{mm}$ diameter. The NIS pellets were prepared by grinding and treating wheat straw, with the particles in the finished pellets having an average particle size of approximately $2.7 \mathrm{~mm}$ (David Cubitt, Sundown Products Ltd., personal communication). The ryegrass used to prepare the silage was harvested using a conditioner mower set to produce a chop length of approximately $20 \mathrm{~mm}$. The mixer wagon used to prepare the TMR had chopping blades, meaning that the untreated straw was chopped to a mean length of $2.9(\mathrm{SD}=1.8) \mathrm{cm}$. The chemical compositions of forages and concentrates offered are presented in Table 2. All components of the diet (grass silage, NIS or straw, and concentrate) were mixed 3 times a week and stored at $4^{\circ} \mathrm{C}$ to preserve nutritional composition, and then fed as a TMR once daily $(0800 \mathrm{~h})$ allowing 5 to $10 \%$ refusals.

\section{Sample Collection}

Feed samples (300 g) of grass silage, NIS, straw, and low- and high-starch concentrates that were used to create the TMR were collected weekly and composited on a per-period basis to be analyzed for nutrient 
Table 1. Ingredient and nutrient compositions (\% of DM unless noted) of experimental diets ${ }^{1}$

\begin{tabular}{|c|c|c|c|c|}
\hline Item & LSTR & LNIS & HSTR & HNIS \\
\hline \multicolumn{5}{|l|}{ Ingredient } \\
\hline Ryegrass silage & 42.4 & 42.4 & 42.4 & 42.4 \\
\hline Straw & 7.6 & - & 7.6 & - \\
\hline NIS & - & 7.6 & - & 7.6 \\
\hline Wheat, rolled ground & 22.0 & 22.0 & 37.5 & 37.5 \\
\hline Corn, distilled dark spirits & 5.4 & 5.4 & 1.7 & 1.7 \\
\hline Soybean meal & 3.5 & 3.5 & 4.4 & 4.4 \\
\hline Soy hulls & 0.5 & 0.5 & 0 & 0 \\
\hline Soy pass & 1.2 & 1.2 & 0.4 & 0.4 \\
\hline Canola meal & 2.7 & 2.7 & 2.8 & 2.8 \\
\hline Molasses & 3.4 & 3.4 & 0.5 & 0.5 \\
\hline Beet pulp, dry & 9.2 & 9.2 & 1.3 & 1.3 \\
\hline Megalac $^{2}$ & 1.1 & 1.1 & 0.2 & 0.2 \\
\hline Limestone, ground & 0.3 & 0.3 & 0.5 & 0.5 \\
\hline Sodium bicarbonate & 0.1 & 0.1 & 0.3 & 0.3 \\
\hline DL-Methionine & 0.1 & 0.1 & 0.1 & 0.1 \\
\hline DL-Lysine & 0.3 & 0.3 & 0.1 & 0.1 \\
\hline Mineral-vitamin & 0.2 & 0.2 & 0.2 & 0.2 \\
\hline \multicolumn{5}{|l|}{ Nutrient composition $^{3}$} \\
\hline DM, \% & 50.0 & 50.1 & 50.2 & 50.0 \\
\hline $\mathrm{CP}$ & 15.9 & 16.0 & 15.7 & 15.8 \\
\hline WSC & 7.85 & 7.84 & 7.04 & 7.03 \\
\hline NDF & 42.3 & 42.1 & 40.3 & 39.5 \\
\hline Starch & 15.7 & 15.8 & 25.3 & 25.4 \\
\hline & 3.49 & 3.46 & 2.54 & 2.51 \\
\hline $\mathrm{ME},{ }^{4} \mathrm{MJ} / \mathrm{kg}$ of $\mathrm{DM}$ & 10.5 & 10.6 & 10.7 & 10.8 \\
\hline
\end{tabular}

${ }^{1}$ Average nutrient composition of experimental diets fed to 16 cows in a $4 \times 4$ Latin square design with 28 -d periods. Values based on nutrient composition of TMR sampled each period. LSTR $=$ low level of starch supplemented with straw; LNIS = low level of starch supplemented with nutritionally improved straw (NIS); HSTR = high level of starch supplemented with straw; HNIS = high level of starch supplemented with NIS.

${ }^{2}$ Volac Wilmar Feed Ingredients Ltd., Hertfordshire, UK.

${ }^{3} \mathrm{WSC}=$ water-soluble carbohydrates; $\mathrm{EE}=$ ether extract.

${ }^{4}$ Calculated using the Cornell Net Carbohydrate and Protein System (Van Amburgh et al., 2015).

composition. Additionally, samples of the TMR offered $(300 \mathrm{~g})$ for each treatment were collected for 3 consecutive days during the sampling period and individually composited on a per-period basis for analysis of nutrient composition. Refusals samples (300 g) of the TMR offered were collected for 3 consecutive days during the sampling period on a per-cow and -period basis. All collected feed samples were stored at $-20^{\circ} \mathrm{C}$ until further laboratory analysis.
Rumen fluid samples were collected from all cows in the lactation and rumen experiments, to measure ruminal fermentation characteristics. Rumen fluid (250 $\mathrm{mL}$ ) was collected from all cows in the lactation trial with a stomach tube (Ruminator, Profs-Products, Wittibreut, Germany) prior to feeding on the last day of each experimental period. Rumen fluid samples from the rumen trial cows were collected for 3 consecutive days during each sampling period. Samples of $250 \mathrm{~mL}$

Table 2. Chemical composition (mean $\pm \mathrm{SD}$ ) of forages and concentrates used in the experiment ${ }^{1}$

\begin{tabular}{|c|c|c|c|c|c|}
\hline Item $^{2}$ & Grass silage & Straw & NIS & LSCON & HSCON \\
\hline $\mathrm{CP}, \%$ of $\mathrm{DM}$ & $12.9 \pm 0.6$ & $3.5 \pm 0.3$ & $4.8 \pm 0.3$ & $19.7 \pm 0.4$ & $19.5 \pm 1.2$ \\
\hline Soluble N, $\%$ of $\mathrm{CP}$ & $64.1 \pm 5.9$ & - & - & - & - \\
\hline $\mathrm{NDF}, \%$ of DM & $57.7 \pm 2.8$ & $87.4 \pm 0.4$ & $77.1 \pm 1.4$ & $21.3 \pm 1.7$ & $16.1 \pm 2.9$ \\
\hline WSC, $\%$ of DM & $7.3 \pm 0.5$ & $1.3 \pm 0.2$ & $1.2 \pm 0.1$ & $9.0 \pm 0.4$ & $7.3 \pm 0.5$ \\
\hline $\mathrm{EE}, \%$ of $\mathrm{DM}$ & $2.83 \pm 0.30$ & $1.37 \pm 0.14$ & $1.00 \pm 0.08$ & $4.25 \pm 0.44$ & $2.35 \pm 0.07$ \\
\hline
\end{tabular}

${ }^{1}$ Average nutrient composition of forages and concentrates included in the experimental diets fed to 16 cows in a crossover design with $28-\mathrm{d}$ periods. Values based on nutrient composition of individual collection of samples each period. NIS $=$ nutritionally improved straw; LSCON $=$ low-starch concentrate; HSCON = high-starch concentrate.

${ }^{2} \mathrm{WSC}=$ water-soluble carbohydrates; $\mathrm{EE}=$ ether extract. 
were collected via previously fitted rumen cannulas at specific time points relative to feeds offered: 0,2 , and 8 $\mathrm{h}$ after morning feeding. The collected rumen fluid for both trials was filtered through a double layer of cheesecloth to remove any feed particles. The $\mathrm{pH}$ was then immediately measured, and 2 subsamples were collected. The first subsample was $0.8 \mathrm{~mL}$ of rumen fluid pipetted into a microcentrifuge tube and diluted with $0.4 \mathrm{~mL}$ deproteinizing solution $(200 \mathrm{~mL} / \mathrm{L}$ of orthophosphoric acid containing $10 \mathrm{mmol} / \mathrm{L}$ of 2-ethylbutyric acid as an internal standard) to later analyze the VFA concentration of the sample. The second subsample was $0.8 \mathrm{~mL}$ of rumen fluid pipetted into a microcentrifuge tube and diluted with $0.48 \mathrm{~mL}$ of trichloroacetate $(25 \mathrm{~g} / \mathrm{L})$ to later analyze the ammonia nitrogen $\left(\mathrm{NH}_{3}-\mathrm{N}\right)$ concentration of the sample. Each subsample was stored at $-20^{\circ} \mathrm{C}$ until later analysis.

Milk yield and composition were analyzed for the cows in the lactation trial. The cows were milked twice a day (0630 and $1630 \mathrm{~h}$ ), and milk yield was recorded for 3 consecutive days during each sampling period before the start of the digestibility measurement period. During these days, milk samples of approximately 50 $\mathrm{mL}$ were collected during each milking and mixed with a milk preservative (bronopol) and stored at approximately $4^{\circ} \mathrm{C}$ until later analysis. Daily milk yield and composition was averaged per cow and period. Following milk yield sampling, the 2 squares in the lactation trial allocated to the digestibility and nitrogen $(\mathrm{N})$ partitioning measurements underwent additional sample collections for 4 consecutive days. Additional milk yield measurements for the 8 cows were recorded and $5-\mathrm{mL}$ samples taken per milking on a per-cow, per-day, perperiod basis; samples were composited and stored at $4^{\circ} \mathrm{C}$ without preservatives until further analysis. Each cow also had a urine and feces separator applied externally for 4 consecutive days during each sampling period (Moorby et al., 2000; Miller et al., 2001). Briefly, a rubberized cloth urine separator was attached over the vulva using hook-and-loop fastenings temporarily glued to the skin of the cow using contact adhesive, with a tube leading to a urine collection container. Feces was collected into a wheelbarrow behind each cow using a rubberized cloth chute held in place using straps connected to a girth strap on the cow and a metal framework behind the animal. The urine and feces separators provided the ability to measure total outputs of excreta, and aliquots of urine $(0.1 \%)$ and feces $(5 \%)$ were collected for further analysis. Urine samples were collected into $1.5 \mathrm{~L}$ of $2 \mathrm{~mol} / \mathrm{L}$ sulfuric acid, with subsamples collected and composited daily throughout the collection period; these were stored at $4^{\circ} \mathrm{C}$ and analyzed immediately at the end of each sampling period.
Feces subsamples were collected and stored in sealed containers at approximately $4^{\circ} \mathrm{C}$ each day; composite samples for each cow were thoroughly mixed at the end of each sampling period and subsampled for immediate analysis for $\mathrm{N}$ concentration. Additional subsamples of composite fecal samples collected from each animal were frozen for subsequent analysis.

The feeds offered and refused were recorded for all cows in the digestibility squares during the $4 \mathrm{~d}$ of the sampling period; samples of $300 \mathrm{~g}$ each were composited for each cow and period and stored at $-20^{\circ} \mathrm{C}$ for laboratory analysis. Body weights and BCS (Edmonson et al., 1989) for all cows in the lactation trial were measured at the beginning of each experimental period and the last day of each sampling period for additional monitoring purposes and analysis of treatment effect.

\section{Sample Analysis}

All analyses (except for urine and feces N) were carried out using freeze-dried material; samples were dried to a constant weight to determine freeze-DM content. Once freeze-dried, the samples were ground to pass through a 1-mm sieve and then analyzed for NDF, water-soluble carbohydrate (WSC), starch, and ether extract, to determine the composition of each diet and feed. Sample ash concentration was determined by combustion at $550^{\circ} \mathrm{C}$ for $6 \mathrm{~h}$ in a muffle furnace. Total $\mathrm{N}$ concentration was determined using a Leco FP 428 nitrogen analyzer (Leco Corporation, St. Joseph, MI) and expressed as $\mathrm{CP}($ total $\mathrm{N} \times 6.25)$ concentration. Fiber analyses were carried out using Fibertec equipment (Tecator Ltd., Thornbury, Bristol, UK). Neutral detergent fiber, assayed with a heat-stable amylase and expressed inclusive of residual ash, was determined as described by Van Soest et al. (1991). Water-soluble carbohydrate concentrations were determined spectrophotometrically using an auto-analyzer (SEAL Analytical Ltd., Southampton, UK) as described by Thomas (1977). Starch concentration was determined as the difference between the initial WSC concentration and WSC concentration (as glucose) determined after boiling in water and subsequent hydrolysis with amyloglucosidase (Sigma-Aldrich Co. Ltd., Poole, UK). A coefficient of 0.9 was used as a factor for converting measured glucose release into the original starch concentration. Briefly, $0.4 \mathrm{~g}$ of sample was refluxed in $80 \mathrm{~mL}$ of deionized water for $30 \mathrm{~min}, 20 \mathrm{~mL}$ of cold acetate buffer (comprising $40 \% \mathrm{vol} / \mathrm{vol} 1 \mathrm{M}$ sodium acetate and $60 \% \mathrm{vol} / \mathrm{vol} 1 \mathrm{M}$ acetic acid) was then added, and the mixture was allowed to cool for $20 \mathrm{~min}$. This was then shaken for $1 \mathrm{~h}$ following addition of $10 \mathrm{~mL}$ of amyloglucosidase solution $(1 \mathrm{~g}$ in $100 \mathrm{~mL}$ of deionized 
water). This solution was then made up to $250 \mathrm{~mL}$ and filtered, and a portion of the filtrate was analyzed for WSC concentration (Thomas, 1977).

Rumen fluid samples collected from both trials to determine VFA composition were analyzed using gas chromatography as described by Zhu et al. (1996). All rumen fluid samples collected for $\mathrm{NH}_{3}-\mathrm{N}$ concentration were determined enzymatically using glutamate dehydrogenase on a discrete analyzer (FP-901M Chemistry Analyzer, Labsystems Oy, Helsinki, Finland; test kit no. 66-50, Sigma-Aldrich Co. Ltd.). The 50-mL preserved (bronopol) milk samples collected from all cows in the lactation trial to determine milk composition were analyzed using near-infrared analysis (National Milk Laboratories, Chippenham, UK). The additional 5-mL milk samples collected from the 8 cows in the digestibility trial were analyzed for $\mathrm{N}$ content from a fresh sample using a Leco FP 428 nitrogen analyzer (Leco Corporation) to further determine feed $\mathrm{N}$ partitioning into milk. Frozen fecal samples were freeze-dried, ground through a 1-mm sieve, and analyzed for NDF, starch, and WSC as described for the feed samples.

\section{Calculations for Total-Tract Digestibility and $N$ Partitioning}

To determine digestibility, the following equation was used:

$$
\begin{gathered}
\operatorname{Digestibility~}_{\mathrm{j}}(\%)=\left(\text { intake }_{\mathrm{j}}-\text { fecal flow }_{\mathrm{j}}\right) \\
\times 100 / \text { intake }_{\mathrm{j}},
\end{gathered}
$$

where $\mathrm{j}=\mathrm{DM}, \mathrm{N}, \mathrm{NDF}$, starch, or WSC.

For N partitioning, the following equations were used:

$$
\begin{gathered}
\text { Milk N (g/d) = milk yield }(\mathrm{kg} / \mathrm{d}) \\
\times \operatorname{milk~N}(\%) / 100 \times 1,000 ;
\end{gathered}
$$

$$
\text { Fecal } \mathrm{N}(\mathrm{g} / \mathrm{d})=\text { fecal DM flow }(\mathrm{kg} / \mathrm{d})
$$

$$
\times \text { fecal N }(\%) / 100 \times 1,000 \text {; }
$$

$$
\text { Urinary } \mathrm{N}(\mathrm{g} / \mathrm{d})=\text { urine weight }(\mathrm{kg} / \mathrm{d})
$$

$\times$ urine $\mathrm{N}$ concentration $(\%) / 100 \times 1,000 ;$

$$
\begin{gathered}
\mathrm{N} \text { balance }(\mathrm{g} / \mathrm{d})=\mathrm{N} \text { intake } \\
-(\text { milk } \mathrm{N}+\text { fecal } \mathrm{N}+\text { urinary } \mathrm{N})
\end{gathered}
$$

Milk $\mathrm{N}$ use efficiency $(\%)=$ milk $\mathrm{N} / \mathrm{N}$ intake $\times 100$.

\section{Statistical Analysis}

All statistical analyses were conducted using JMP (version 13; SAS Institute Inc., Cary, NC), and results were analyzed using a mixed effects model. The model accounted for fixed effects of starch level (low and high), straw type (NIS and straw), interaction between starch level and straw type, period (1 to 4 ), and square ( 1 to 3 for lactation data and 1 to 2 for digestibility). The random effect of the model was the animal (1 to 12 for lactation trial, 1 to 8 for the digestibility measurements, and 13 to 16 for the rumen trial). Moreover, for rumen fermentation characteristics of the rumen trial, the model included the hour of sampling relative to feeding (hour: 0, 2, or 8) as a fixed effect. Differences between means of treatments were tested using the Tukey option when a significant interaction was identified, and statistical significance was declared at $P$ $<0.05$ and tendency at $0.1 \leq P \geq 0.05$.

\section{RESULTS}

\section{Animal Performance}

The DMI for the rumen trial is presented in Table 3. The straw type included in the diet affected the DMI, resulting in a $0.7 \mathrm{~kg} / \mathrm{d}$ increase when fed NIS compared with straw. However, starch level did not have an effect. The DMI for the lactation trial increased by $1.6 \mathrm{~kg} / \mathrm{d}$ when fed NIS and $1.5 \mathrm{~kg} / \mathrm{d}$ when low-starch diets were fed (Table 4). Additionally, a tendency of interaction between the straw type and starch level of the diet was detected; when low starch + NIS was fed, DMI tended to be $3.2 \mathrm{~kg} / \mathrm{d}$ higher compared with when high starch + untreated straw was fed.

Milk yield was on average $25.9 \mathrm{~kg} / \mathrm{d}$, and it was affected by straw type $(P=0.01$; Table 4$)$; diets including NIS resulted in a $1.7 \mathrm{~kg} / \mathrm{d}$ higher milk yield. The inclusion of NIS in diets resulted in increased milk protein and lactose yields (9.9 and 8.6\%, respectively) and a tendency for higher milk fat yield compared with untreated straw diets. Starch levels of the diet affected fat yield, increasing levels by $0.06 \mathrm{~kg} / \mathrm{d}$ in low-starch diets. Milk protein content was increased when NIS was fed, but fat content remained unaffected. High-starch diets increased milk protein content by $2.7 \%$ compared with low-starch diets; starch level did not affect fat or lactose levels. Furthermore, MUN averaged $6.26 \mathrm{mg} /$ $\mathrm{dL}$ and was not affected by treatments. The interaction between straw type and starch level were not significant for any variables measured. 
Table 3. Effect of straw type (STR) and starch level (STA) on DMI and rumen fermentation characteristics in dry dairy cows (trial 2) ${ }^{1}$

\begin{tabular}{|c|c|c|c|c|c|c|c|c|}
\hline Item & \multicolumn{4}{|c|}{ Diet } & SEM & \multicolumn{3}{|c|}{$P$-value } \\
\hline \multicolumn{8}{|l|}{ Rumen fermentation characteristics ${ }^{2}$} & 0.17 \\
\hline \multicolumn{9}{|l|}{$0 \mathrm{~h}$ after feeding } \\
\hline $\mathrm{pH}$ & 6.94 & 6.96 & 7.04 & 7.00 & 0.04 & 0.25 & 0.33 & 0.91 \\
\hline $\mathrm{NH}_{3}-\mathrm{N}, \mathrm{mg} / 100 \mathrm{~mL}$ & 5.99 & 5.83 & 5.95 & 5.73 & 0.76 & 0.62 & 0.86 & 0.63 \\
\hline Acetate & 67.4 & 67.1 & 65.8 & 64.8 & 2.59 & 0.82 & 0.48 & 0.89 \\
\hline Propionate & 15.0 & 13.2 & 14.4 & 15.4 & 2.13 & 0.84 & 0.70 & 0.50 \\
\hline Butyrate & 14.9 & 14.0 & 14.0 & 16.7 & 1.1 & 0.60 & 0.52 & 0.28 \\
\hline $\mathrm{BCVFA}^{3}$ & 1.57 & 2.58 & 2.24 & 1.68 & 0.48 & 0.98 & 0.83 & 0.36 \\
\hline \multicolumn{9}{|l|}{$2 \mathrm{~h}$ after feeding } \\
\hline $\mathrm{pH}$ & 6.42 & 6.50 & 6.46 & 6.42 & 0.04 & 0.25 & 0.33 & 0.91 \\
\hline $\mathrm{NH}_{3}-\mathrm{N}, \mathrm{mg} / 100 \mathrm{~mL}$ & 17.5 & 17.2 & 17.3 & 17.2 & 0.8 & 0.62 & 0.86 & 0.63 \\
\hline BCVFA & 2.08 & 2.66 & 1.49 & 2.41 & 0.22 & $<0.01$ & 0.04 & 0.35 \\
\hline \multicolumn{9}{|l|}{$8 \mathrm{~h}$ after feeding } \\
\hline $\mathrm{pH}$ & 6.21 & 6.32 & 6.18 & 6.24 & 0.04 & 0.25 & 0.33 & 0.91 \\
\hline $\mathrm{NH}_{3}-\mathrm{N}, \mathrm{mg} / 100 \mathrm{~mL}$ & 7.50 & 6.83 & 6.96 & 7.25 & 0.76 & 0.62 & 0.86 & 0.63 \\
\hline $\mathrm{VFA}, \mathrm{m} M$ & 79.4 & 83.2 & 88.0 & 98.1 & 5.0 & 0.26 & 0.08 & 0.60 \\
\hline \multicolumn{9}{|l|}{ VFA profile, $\mathrm{mol} / 100 \mathrm{~mol}$} \\
\hline Acetate & 63.9 & 59.8 & 61.0 & 57.0 & 2.9 & 0.24 & 0.39 & 0.99 \\
\hline Propionate & 15.2 & 19.5 & 17.2 & 19.8 & 2.0 & 0.14 & 0.60 & 0.71 \\
\hline Butyrate & 16.9 & 15.5 & 16.7 & 18.2 & 1.2 & 0.97 & 0.40 & 0.36 \\
\hline BCVFA & 1.76 & 1.58 & 1.52 & 2.01 & 0.27 & 0.60 & 0.75 & 0.28 \\
\hline
\end{tabular}

${ }^{\mathrm{a}, \mathrm{b}}$ Within a row, means without a common superscript differ $(P<0.05)$.

${ }^{1}$ LSTR = low level of starch supplemented with straw; LNIS = low level of starch supplemented with nutritionally improved straw (NIS); HSTR $=$ high level of starch supplemented with straw; HNIS = high level of starch supplemented with NIS

${ }^{2}$ Differences in hours are statistically significant $(P<0.001)$ for both $\mathrm{pH}$ and $\mathrm{NH}_{3}-\mathrm{N}$, with no interaction with experimental factors.

${ }^{3} \mathrm{BCVFA}=$ branched-chain VFA.

\section{Ruminal Fermentation Characteristics}

The effects of straw type and starch level of the diet on ruminal $\mathrm{pH}$, VFA concentration, and $\mathrm{NH}_{3}-\mathrm{N}$ concentration for the rumen trial is presented in Table 3.
Mean ruminal $\mathrm{pH}$ and $\mathrm{NH}_{3}-\mathrm{N}$ concentration were not affected by straw type or starch level. Prior to feeding $(0 \mathrm{~h})$, the total VFA concentration and profile were also not affected. At $2 \mathrm{~h}$ relative to feeding, the total VFA concentration average was $91.7 \mathrm{~m} M$ and was affected

Table 4. Effect of straw type (STR) and starch level (STA) on DMI, milk yield (MY), and milk composition in lactating dairy cows ${ }^{1}$

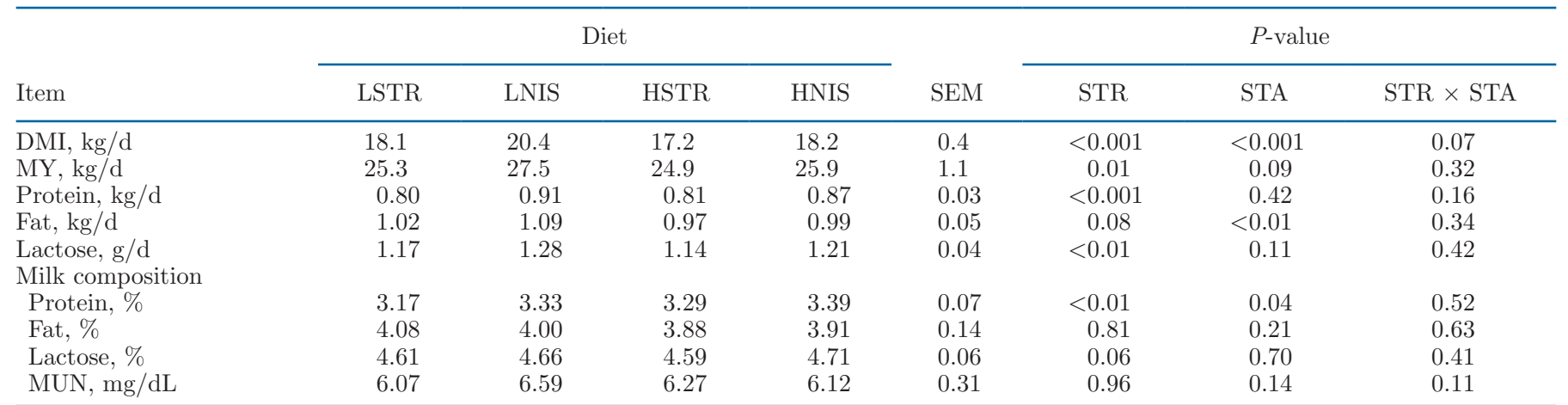

${ }^{1}$ LSTR = low level of starch supplemented with straw; LNIS = low level of starch supplemented with nutritionally improved straw (NIS); HSTR $=$ high level of starch supplemented with straw; HNIS = high level of starch supplemented with NIS. 
Table 5. Effect of straw type (STR) and starch level (STA) on rumen fermentation characteristics in lactating dairy cows ${ }^{1}$

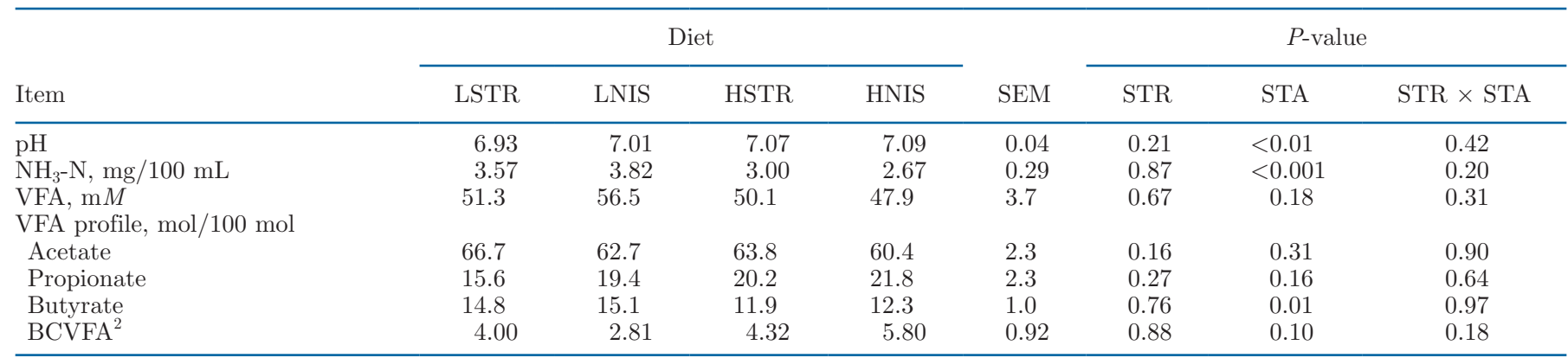

${ }^{1}$ LSTR = low level of starch supplemented with straw; LNIS = low level of starch supplemented with nutritionally improved straw (NIS); HSTR $=$ high level of starch supplemented with straw; HNIS = high level of starch supplemented with NIS.

${ }^{2} \mathrm{BCVFA}=$ branched-chain VFA.

by the starch level of the diet, increasing by $13.8 \%$ in high-starch diets. The interaction between straw type and starch level also significantly affected VFA concentration $(P=0.03)$, where higher VFA concentrations were observed for NIS-fed diets only at the low-starch level. Moreover, the inclusion of NIS resulted in a decrease in acetate concentration and an increase in branched-chain VFA concentrations compared with untreated straw at $2 \mathrm{~h}$ relative to feeding. At $8 \mathrm{~h}$ relative to feeding, no significant differences were detected between ruminal fermentation characteristics, with the exception of total VFA concentrations, which tended $(P=0.08)$ to increase with higher starch levels. The rumen characteristics for the lactation trial at $0 \mathrm{~h}$ relative to feeding are presented in Table 5 . The average $\mathrm{NH}_{3}-\mathrm{N}$ concentration was $3.3 \mathrm{mg} / 100 \mathrm{~mL}$, and low-starch diets increased levels by $0.9 \mathrm{mg} / 100 \mathrm{~mL}$ compared with highstarch diets. The total VFA concentration and profile were not affected by straw type or starch level of the diet, except for the butyrate concentration $(P=0.01)$, which was higher in low-starch diets.

\section{Total-Tract Digestibility and N Partitioning}

Intake, fecal flow, and digestibility of DM, NDF, starch, and WSC are described in Table 6. The intake of DM had trends similar to those shown in Table 4; however, they are different in numbers due to different days and Latin squares used for the digestibility measurements. Low-starch diets and diets with inclusion of NIS resulted in an increase of DM fecal outflow. However, untreated straw resulted in a $2.7 \%$ increase in DM total-tract digestibility. The NDF intake, fecal flow, and total-tract digestibility were all significantly affected by straw type; intake and fecal flow were seen to be higher when NIS was fed compared with

Table 6. Effect of straw type (STR) and starch level (STA) on intake, fecal flow, and digestibility of nutrients of experimental diets ${ }^{1}$

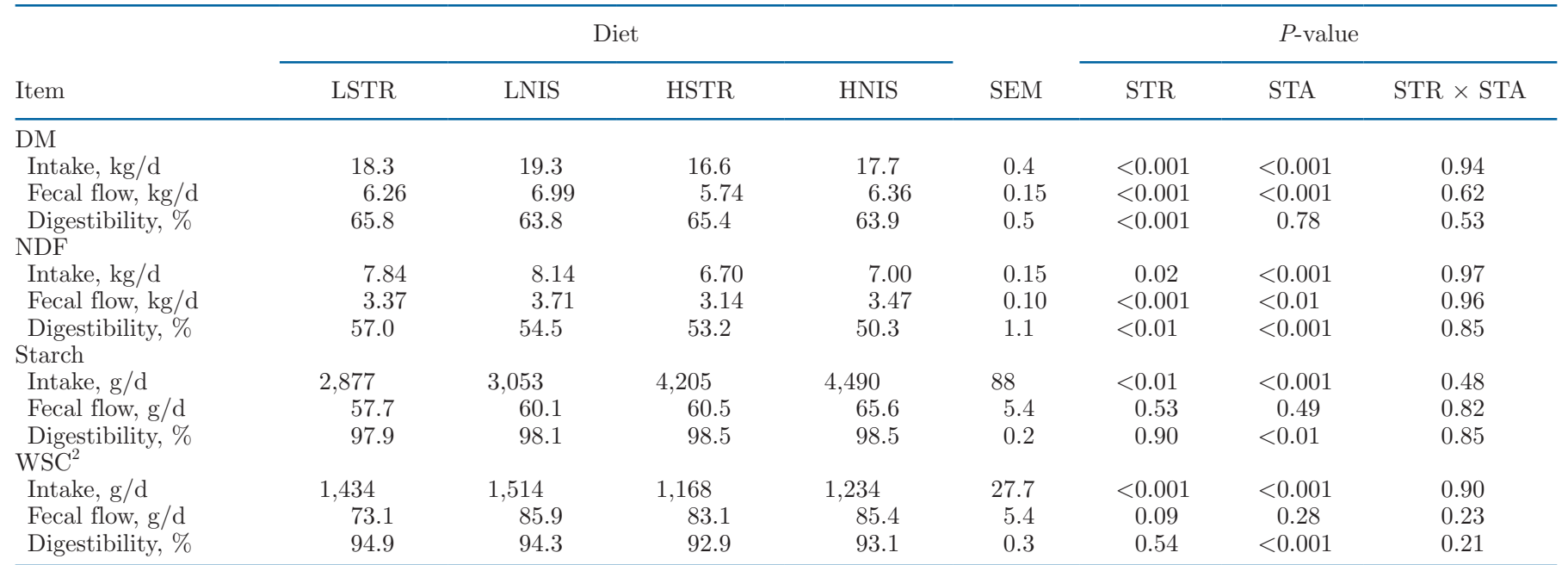

${ }^{1}$ LSTR $=$ low level of starch supplemented with straw; LNIS = low level of starch supplemented with nutritionally improved straw (NIS); HSTR $=$ high level of starch supplemented with straw; HNIS = high level of starch supplemented with NIS.

${ }^{2} \mathrm{WSC}=$ water-soluble carbohydrates. 
untreated straw, whereas digestibility was higher in untreated-straw diets. Low-starch diets increased intake, fecal flow, and total-tract digestibility compared with high-starch diets.

The average starch intake was $3.7 \mathrm{~kg} / \mathrm{d}$, and highstarch diets resulted in a $21.4 \%$ higher intake compared with low-starch diets, whereas inclusion of NIS also increased starch intake by $6.5 \%$ compared with untreated straw. Similarly, the total-tract digestibility of starch was increased by $0.5 \%$ when high-starch diets were fed. The straw type of the diet did not appear to affect the fecal output or total-tract digestibility of starch. Similarly, intake and total-tract digestibility of WSC were affected $(P<0.001)$ by the starch level; however, they were increased in low-starch diets. The inclusion of NIS in diets significantly affected WSC intake, increasing it by $5.9 \%$ compared with untreated straw. Fecal flow of WSC also tended $(P=0.09)$ to increase with inclusion of NIS.

The $\mathrm{N}$ intake, milk $\mathrm{N}$, and $\mathrm{N}$ in feces and urine, along with whole-body $\mathrm{N}$ balance data, are presented in Table 7. The inclusion of NIS in diets and low-starch diets increased $\mathrm{N}$ intake by 10.4 and $6.7 \%$, respectively. Mean $\mathrm{N}$ intake was $456 \mathrm{~g} / \mathrm{d}$, and the amount of $\mathrm{N}$ excreted in feces averaged $158 \mathrm{~g} / \mathrm{d}$, resulting in fecal $\mathrm{N}$ output representing an average of $34.7 \%$ of $\mathrm{N}$ intake. The inclusion of NIS in diets also increased the amount of $\mathrm{N}$ in milk, resulting in $13 \mathrm{~g} / \mathrm{d}$ more $\mathrm{N}$. The average $\mathrm{N}$ in milk was $144 \mathrm{~g} / \mathrm{d}$, making milk $\mathrm{N}$ use efficiency on average $31.6 \%$. The $\mathrm{N}$ content of feces was also significantly affected $(P<0.001)$ by the straw type and starch level of the diet. Diets containing NIS showed $10.6 \%$ higher $\mathrm{N}$ content, whereas low-starch diets were $14.9 \%$ higher compared with high-starch diets. This resulted in higher apparent $\mathrm{N}$ digestibility for high-starch diets $(P=0.05)$. The level of starch had a tendency $(P$ $=0.07$ ) to affect the $\mathrm{N}$ content of urine, proving to be $12 \mathrm{~g} / \mathrm{d}$ higher from cows fed low-starch diets. An aver- age of $132 \mathrm{~g} / \mathrm{d}$ of $\mathrm{N}$ was excreted in urine, representing, on average, $28.9 \%$ of $\mathrm{N}$ intake.

\section{DISCUSSION}

\section{Animal Performance}

Average DMI of the cows in the lactation trial was $18.5 \mathrm{~kg} / \mathrm{d}$, which is similar to the DMI for lactating dairy cows reported in similar studies in our laboratory (Moorby et al., 2006, 2009, 2016). In the current study, the cows in the lactation trial were seen to have a higher DMI when fed diets with low starch levels compared with high. Little agreement exists in the literature about the effects of dietary starch concentrations on DMI; the regulation of DMI is a complex issue because several factors contribute to it. Hatew et al. (2015) reported similar findings to those in the current study when feeding low-starch compared with high-starch diets, in which DMI was $4.3 \%$ higher for low-starch diets. The findings of Miron et al. (2004) were also in agreement, reporting a reduced DMI in high-starch concentrate diets compared with high-NDF concentration diet. However, other studies have found that feeding low-starch diets to cows resulted in reduced DMI (Oba and Allen, 2003; McCarthy et al., 2015). These studies reported that diets with high levels of starch (31.7 and $26.2 \%$ of DM, respectively), compared with low levels (21.2 and $21.5 \%$ of $\mathrm{DM}$ ), increased DMI by 2.0 and $0.8 \mathrm{~kg} / \mathrm{d}$. Allen et al. (2009) suggested that high-starch diets result in higher propionic acid production due to increased starch fermentation in the rumen, which may decrease DMI due to hepatic oxidation. Increasing propionate as a proportion of VFA absorbed from the rumen causes its flux to the liver to increase during meals (Benson et al., 2002), where it stimulates oxidation by the liver, causing stimulation of a signal to the brain to reduce feed intake. In

Table 7. Effect of straw type (STR) and starch level (STA) on nitrogen (N) content in milk, feces, and urine and nitrogen balance in lactating dairy cows

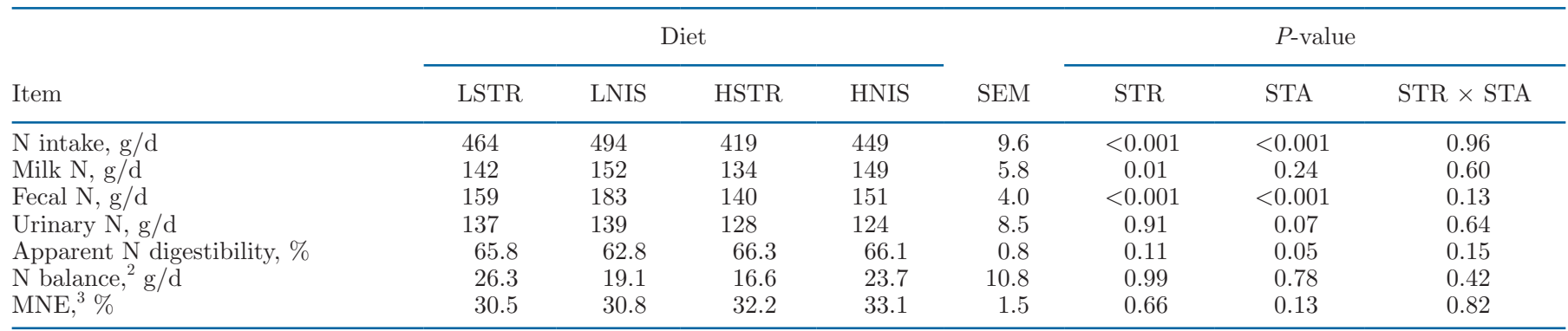

${ }^{1}$ LSTR = low level of starch supplemented with straw; LNIS = low level of starch supplemented with nutritionally improved straw (NIS); HSTR $=$ high level of starch supplemented with straw; HNIS = high level of starch supplemented with NIS.

${ }^{2} \mathrm{~N}$ balance $=\mathrm{N}$ intake $-($ milk $\mathrm{N}+$ fecal $\mathrm{N}+$ urinary $\mathrm{N})$.

${ }^{3}$ Milk nitrogen use efficiency; calculated as milk N/N intake $\times 100$. 
the literature, most studies investigating the effects of different starch levels in lactating cows' diets replaced NDF sources with starchy ones (Oba and Allen, 2003; Miron et al., 2004; Hatew et al., 2015; McCarthy et al., 2015). This led de facto to an imbalance in ME supply. In the current study, the lower supply of starch, and therefore ME, was balanced with the addition of WSC, fat, and NDF sources, instead of just NDF (Table 1). This resulted in isoenergetic diets, in which the sources of energy were different but the potential ME supply was the same. This is likely the reason why, in the current study, the rumen propionic acid concentration was not significantly different between low- and highstarch diets. However, the uptake of propionate by the liver was not measured in the current study, nor were the other factors that could potentially cause a flux of propionate into the rumen, affecting concentrations there (Hall et al., 2015).

Cows fed NIS had a higher DMI compared with those fed untreated straw. Other studies evaluating the inclusion of $\mathrm{NaOH}$-treated forages reported similar findings. Canale et al. (1988) found that when $\mathrm{NaOH}$-treated alfalfa-orchard grass hay was fed, DMI increased by 1.2 $\mathrm{kg} / \mathrm{d}$ compared with untreated hay. In contrast, Jami et al. (2014), found that DMI decreased by $1.2 \mathrm{~kg} / \mathrm{d}$ when feeding $\mathrm{NaOH}$-treated corn straw compared with wheat hay.

Huhtanen and Hristov (2009) conducted a metaanalysis using a data set from Northern Europe and North America and reported that DMI and milk production are highly correlated. Indeed, in the current study, the inclusion of NIS and low starch level, which resulted in higher DMI, also resulted in higher milk yield for NIS and a tendency for higher milk yield for low-starch diets. The higher milk yield with the inclusion of $\mathrm{NaOH}$-treated straw agrees with results found by Canale et al. (1988), who reported that $\mathrm{NaOH}$-treated alfalfa-orchard grass hay compared with untreated hay resulted in a $1.4 \mathrm{~kg} / \mathrm{d}$ higher milk yield. Milk protein and lactose yields were also all higher when fed NIS diets compared with untreated straw. In contrast, past studies have not found that $\mathrm{NaOH}$-treated forages significantly affected milk protein and fat yield (Canale et al., 1988; Leaver and Hill, 1995).

An increase in milk yield could influence milk protein yield and content (Jami et al., 2014). The current study supported this, with the $1.7 \mathrm{~kg} / \mathrm{d}$ increase in milk yield when fed NIS being accompanied by a $0.09 \mathrm{~kg} / \mathrm{d}$ increase in milk protein yield and a $4.0 \%$ increase in protein content. Another factor that can influence milk protein yield is the total $\mathrm{N}$ intake (Huhtanen and Hristov, 2009). In this study, NIS diets resulted in increasing $\mathrm{N}$ intake by $30 \mathrm{~g} / \mathrm{d}$. Increasing $\mathrm{N}$ intake can have a positive effect of microbial protein synthesis, which is the primary source of amino acids used for energy for milk production and composition yield (Kalscheur et al., 2006). In contrast, Jami et al. (2014) reported a 0.5 $\mathrm{kg} / \mathrm{d}$ increase in milk yield when cows were fed $\mathrm{NaOH}-$ treated corn straw, which resulted in higher milk protein and fat contents. Even though we reported higher milk yield and increased milk fat yield for cows fed NIS, the fat content was not affected in the current study.

Milk fat yield is highly influenced by acetate absorption, which increases the expression of lipogenic enzymes in the bovine mammary gland and is a major substrate for de novo fatty acid synthesis (Urrutia and Harvatine, 2017). Although the ruminal concentration is not the most suitable way to measure the flux (Hall et al., 2015), in the current study ruminal acetate proportion at $2 \mathrm{~h}$ after feeding was lower for NIS diets (Table 3). This could be due to a difference in absorption and passage of VFA and rumen fluid volume across treatments (Hall et al., 2015), which were not measured in this study. Moreover, milk fat concentration did not differ with NIS supplementation, and the tendency for increased milk fat yield could also potentially reflect the increased milk yield of cows fed with NIS. Similarly, increased protein milk yields and concentration among NIS-supplemented cows reflects the higher protein intakes observed $(29.7 \mathrm{~g} / \mathrm{d}$ higher for NIS diets relative to untreated straw diets). Additionally, the starch level affected the milk fat yield; a higher milk fat yield in low-starch diets could potentially be a result of low starch levels having a higher NDF concentration, which is consistent with the outcome when NIS was included. The MUN for the treatments averaged $6.26 \mathrm{mg} / \mathrm{dL}$, which is relatively low but within the normal range observed in dairy cattle (3.6 to $13.1 \mathrm{mg} / \mathrm{dL}$; Spek et al., 2013). This is the result of the relatively high milk $\mathrm{N}$ use efficiency (MNE) observed in the current study. Indeed, an average MNE of $27.7 \%$ was reported for North European studies (Huhtanen and Hristov, 2009), whereas the current study had an average MNE of $31.7 \%$. For the current study, we formulated the experimental diets using the Cornell Net Carbohydrate and Protein System, which was recently upgraded, especially in its protein submodel, and the evaluation indicated that it is capable of formulating low-CP diets without reducing milk yield (Van Amburgh et al., 2015).

\section{Rumen Fermentation and Nutrient Digestibility}

Ruminal $\mathrm{pH}$ for the rumen-trial cows was not affected by treatment. The $\mathrm{pH}$ remained above 6.0 for all hours of sampling for both trials. This may potentially be due to the higher level of NDF in the diets, averaging $41.0 \%$ of DM, which would allow for a more optimal rumen balance of VFA production, reducing the risk of 
lowered pH (Plaizier et al., 2008). The ruminal concentration of $\mathrm{NH}_{3}-\mathrm{N}$ was not affected by treatment in the rumen trial; however, it was affected by the starch level of the diet in the lactation trial. When low-starch diets were fed, the $\mathrm{NH}_{3}-\mathrm{N}$ concentration was higher than when high-starch diets were fed. Higher levels of starch can result in a more rapidly available source of energy for microbes, whereby higher utilization of the excess of ruminal $\mathrm{NH}_{3}-\mathrm{N}$ and increase in microbial growth will occur (Bach et al., 2005; Calsamiglia et al., 2010). This could potentially be the result of lower $\mathrm{NH}_{3}-\mathrm{N}$ levels in high-starch diets. In this case, this could be beneficial to improving the $\mathrm{N}$ use efficiency of the cow by reducing the amount of excess $\mathrm{N}$ excreted and ultimately reducing N pollution (Foskolos and Moorby, 2018; Soteriades et al., 2018). This was supported by our study, with both urinary and fecal $\mathrm{N}$ excretion being lower from cows offered high-starch diets, indicating that more $\mathrm{NH}_{3}-\mathrm{N}$ was utilized in the rumen instead of being absorbed and excreted.

As discussed previously, DMI was seen to be highest with inclusion of NIS. However, total-tract digestibility of DM and NDF was reduced when NIS was fed. Assuming first-order digestion kinetics in the rumen, the amount of feed degradation in the rumen is determined by 2 factors: the degradation rate of the feed fraction and its passage rate (Ørskov and McDonald, 1979). Previous analysis using the in vitro system suggested that the degradable fraction of NDF of untreated straw was $67 \%$ NDF (Raffrenato et al., 2018), and that of NIS was 78\% (David Cubitt, Sundown Products Ltd., personal communication). Unfortunately, we did not analyze lignin or undigested NDF content for untreated straw and NIS, but we did measure total-tract NDF digestibility. It should be noted that future use of the approach taken in this experiment would ideally include characterization of the lignin and undigested $\mathrm{NDF}$ values for both untreated and $\mathrm{NaOH}$-treated straw to reduce variability. However, when a feed with a higher passage rate is spending less time in the rumen, this will result in less degradation of nutrients. Most empirical equations used to predict the passage rate of feeds incorporate DMI as an input (Volden and Larsen, 2011; Van Amburgh et al., 2015). However, the relationship between passage rate and DMI is recognized, because the passage of feed residues out of the rumen is needed for further intake to occur (Krizsan et al., 2010). Therefore, in the current study, the higher DMI of NIS-fed cows may have affected passage rate, resulting in reduced DM and NDF digestibility.

As expected, higher DMI for NIS and low-starch diets resulted in higher $\mathrm{N}$ intake, because all diets were formulated to be isonitrogenous. The positive relationship between rumen $\mathrm{NH}_{3}-\mathrm{N}$ concentration and urinary
$\mathrm{N}$ excretion is well documented (Bach et al., 2005; Calsamiglia et al., 2010). Therefore, the tendency for lower urinary $\mathrm{N}$ with high-starch diets can be attributed to the lower $\mathrm{NH}_{3}-\mathrm{N}$ concentrations measured with lactating cows at $0 \mathrm{~h}$ relative to feeding. Following the same trends discussed previously on DMI and DM and NDF digestibility, $\mathrm{N}$ digestibility was lower for high-starch diets where both DM intake and $\mathrm{N}$ intake were lower. Consequently, fecal $\mathrm{N}$ excretion was lower for highstarch diets. Thus, feeding high-starch diets is likely to reduce $\mathrm{N}$ excretion from dairy cows. However, this was coupled with a reduction in milk production, such that overall MNE was not improved.

\section{CONCLUSIONS}

Results from this study demonstrated that dairy cows benefited from the inclusion of NIS in the diets. Inclusion of NIS improved DMI, resulting in a higher milk yield. A higher milk yield due to dietary inclusion of NIS also improved milk protein yield and content due to higher $\mathrm{N}$ intake. High starch levels in diets did not affect performance; however, inclusion of NIS with low starch levels was the most beneficial. These results illustrate that feeding NIS to lactating dairy cows at low or high starch levels had a positive effect on performance. These results can be used to further increase production levels in the dairy industry.

\section{ACKNOWLEDGMENTS}

This study received funding from Wynnstay Group Plc (Llansantffraid, UK), Sundown Products Ltd. (Huntingdon, UK), the Welsh Government (Cardiff, UK) and Higher Education Funding Council for Wales (Bedwas, UK) through the Sêr Cymru National Research Network for Low Carbon, Energy and Environment (Project: "Cleaner Cows"), and the European Union's Horizon 2020 research and innovation program (Brussels, Belgium) under the Marie 414 Skłodowska-Curie grant agreement No. 777974 (Project: CowficieNcy). The authors thank Naomi Gordon and other research and farm staff at Aberystwyth University's Trawscoed Research Farm, and the staff of the university's Analytical Chemistry Laboratory (Aberystwyth, UK). The authors have not stated any conflicts of interest.

\section{REFERENCES}

Albornoz, R. I., K. J. Harvatine, and M. S. Allen. 2019. Diet starch concentration and starch fermentability affect energy intake and energy balance of cows in the early postpartum period. J. Dairy Sci. 102:5161-5171. https://doi.org/10.3168/jds.2018-15634.

Allen, M. S., B. J. Bradford, and M. Oba. 2009. Board-invited review: The hepatic oxidation theory of the control of feed intake and its 
application to ruminants. J. Anim. Sci. 87:3317-3334. https://doi org/10.2527/jas.2009-1779.

Bach, A., S. Calsamiglia, and M. D. Stern. 2005. Nitrogen metabolism in the rumen. J. Dairy Sci. 88:E9-E21. https://doi.org/10.3168/ jds.S0022-0302(05)73133-7.

Benson, J. A., C. K. Reynolds, P. C. Aikman, B. Lupoli, and D. E. Beever. 2002. Effects of abomasal vegetable oil infusion on splanchnic nutrient metabolism in lactating dairy cows. J. Dairy Sci. 85:1804-1814. https://doi.org/10.3168/jds.S0022-0302(02)74255 $-0$.

Boerman, J. P., S. B. Potts, M. J. VandeHaar, M. S. Allen, and A. L. Lock. 2015. Milk production responses to a change in dietary starch concentration vary by production level in dairy cattle. J. Dairy Sci. 98:4698-4706. https://doi.org/10.3168/jds.2014-8999.

Calsamiglia, S., M. Blanch, A. Ferret, and D. Moya. 2012. Is subacute ruminal acidosis a $\mathrm{pH}$ related problem? Causes and tools for its control. Anim. Feed Sci. Technol. 172:42-50. https://doi.org/10 .1016/j.anifeedsci.2011.12.007.

Calsamiglia, S., A. Ferret, C. K. Reynolds, N. B. Kristensen, and A. M. van Vuuren. 2010. Strategies for optimizing nitrogen use by ruminants. Animal 4:1184-1196. https://doi.org/10.1017/ S1751731110000911.

Canale, C., S. Abrams, L. Muller, W. Kjelgaard, P. Anderson, and H. Harpster. 1988. Alkali-Treated forage for early lactation dairy cows: Effect on lactation performance and nutrient digestibility. J. Dairy Sci. 71:2166-2174. https://doi.org/10.3168/jds.S0022 -0302(88)79789-1.

Dijkstra, J., J. L. Ellis, E. Kebreab, A. B. Strathe, S. López, J. France, and A. Bannink. 2012. Ruminal pH regulation and nutritional consequences of low pH. Anim. Feed Sci. Technol. 172:22-33. https:// doi.org/10.1016/j.anifeedsci.2011.12.005.

Duffield, T. F., A. R. Rabiee, and I. J. Lean. 2008. A meta-analysis of the impact of monensin in lactating dairy cattle. Part 2. Production effects. J. Dairy Sci. 91:1347-1360. https://doi.org/10.3168/ jds.2007-0608.

Edmonson, A. J., I. J. Lean, L. D. Weaver, T. Farver, and G. Webster. 1989. A body condition scoring chart for Holstein dairy cows. J. Dairy Sci. 72:68-78. https://doi.org/10.3168/jds.S0022 $-0302(89) 79081-0$.

Foskolos, A., and J. M. Moorby. 2018. Evaluating lifetime nitrogen use efficiency of dairy cattle: A modelling approach. PLoS One 13:e0201638. https://doi.org/10.1371/journal.pone.0201638.

Hall, M. B., T. D. Nennich, P. H. Doane, and G. E. Brink. 2015. Total volatile fatty acid concentrations are unreliable estimators of treatment effects on ruminal fermentation in vivo. J. Dairy Sci. 98:3988-3999.

Hatew, B., S. C. Podesta, H. Van Laar, W. F. Pellikaan, J. L. Ellis, J. Dijkstra, and A. Bannink. 2015. Effects of dietary starch content and rate of fermentation on methane production in lactating dairy cows. J. Dairy Sci. 98:486-499. https://doi.org/10.3168/jds.2014 -8427 .

Hinkelmann, K., and O. Kempthorne. 2008. Chapter 10. Latin square type designs. Pages 373-417 in Design and Analysis of Experiments, Volume 1: Introduction to Experimental Design. 2nd ed. John Wiley and Sons Inc, Hoboken, NJ.

Huhtanen, P., and A. N. Hristov. 2009. A meta-analysis of the effects of dietary protein concentration and degradability on milk protein yield and milk N efficiency in dairy cows. J. Dairy Sci. 92:32223232. https://doi.org/10.3168/jds.2008-1352.

Humer, E., R. M. Petri, J. R. Aschenbach, B. J. Bradford, G. B. Penner, M. Tafaj, K. H. Südekum, and Q. Zebeli. 2018. Invited review: Practical feeding management recommendations to mitigate the risk of subacute ruminal acidosis in dairy cattle. J. Dairy Sci. 101:872-888. https://doi.org/10.3168/jds.2017-13191.

Jami, E., N. Shterzer, E. Yosef, M. Nikbachat, J. Miron, and I. Mizrahi. 2014. Effects of including $\mathrm{NaOH}$-treated corn straw as a substitute for wheat hay in the ration of lactating cows on performance, digestibility, and rumen microbial profile. J. Dairy Sci. 97:1623-1633. https://doi.org/10.3168/jds.2013-7192.

Kalscheur, K. F., R. L. Baldwin, B. P. Glenn, and R. A. Kohn. 2006. Milk production of dairy cows fed differing concentrations of ru- men-degraded protein. J. Dairy Sci. 89:249-259. https://doi.org/ 10.3168/jds.S0022-0302(06)72089-6.

Krizsan, S. J., S. Ahvenjärvi, and P. Huhtanen. 2010. A meta-analysis of passage rate estimated by rumen evacuation with cattle and evaluation of passage rate prediction models. J. Dairy Sci. 93:5890-5901. https://doi.org/10.3168/jds.2010-3457.

Leaver, J. D., and J. Hill. 1995. The performance of dairy cows offered ensiled while-crop wheat, urea-treated whole crop wheat or sodium hydroxide-treated wheat grain and wheat straw in a mixture with grass silage. Anim. Sci. 61:481-489. https://doi.org/10.1017/ S1357729800014041.

McCarthy, M. M., T. Yasui, C. M. Ryan, G. D. Mechor, and T. R. Overton. 2015. Performance of early-lactation dairy cows as affected by dietary starch and monensin supplementation. J. Dairy Sci. 98:3335-3350. https://doi.org/10.3168/jds.2014-8820.

Mertens, D. R. 2005. Rate and extent of digestion. Pages 13-47 in Quantitative Aspects of Ruminant Nutrition and Metabolism. J. Dijkstra, J. M. Forbes, and J. France, ed. CAB International Publishing, Wallingford, UK.

Miller, L. A., J. M. Moorby, D. R. Davies, M. O. Humphreys, N. D. Scollan, J. C. MacRae, and M. K. Theodorou. 2001. Increased concentration of water-soluble carbohydrate in perennial ryegrass ( $\mathrm{Lo}$ lium perenne L.): Milk production from late-lactation dairy cows. Grass Forage Sci. 56:383-394. https://doi.org/10.1046/j.1365-2494 2001.00288.x.

Miron, J., E. Yosef, M. Nikbachat, A. Zenou, E. Maltz, I. Halachmi, and D. Ben-Ghedalia. 2004. Feeding behavior and performance of dairy cows fed pelleted nonroughage fiber byproducts. J. Dairy Sci. 87:1372-1379. https://doi.org/10.3168/jds.S0022-0302(04)73286 -5 .

Moorby, J. M., R. J. Dewhurst, J. K. S. Tweed, M. S. Dhanoa, and N. F. G. Beck. 2000. Effects of altering the energy and protein supply to dairy cows during the dry period. 2. Metabolic and hormonal responses. J. Dairy Sci. 83:1795-1805. https://doi.org/10.3168/jds .S0022-0302(00)75050-8.

Moorby, J. M., N. M. Ellis, and D. R. Davies. 2016. Assessment of dietary ratios of red clover and corn silages on milk production and milk quality in dairy cows. J. Dairy Sci. 99:7982-7992. https://doi .org/10.3168/jds.2016-11150.

Moorby, J. M., R. T. Evans, N. D. Scollan, J. C. MacRae, and M. K. Theodorou. 2006. Increased concentration of water-soluble carbohydrate in perennial ryegrass (Lolium perenne L.). Evaluation in dairy cows in early lactation. Grass Forage Sci. 61:52-59. https:// doi.org/10.1111/j.1365-2494.2006.00507.x.

Moorby, J. M., M. R. F. Lee, D. R. Davies, E. J. Kim, G. R. Nute, N. M. Ellis, and N. D. Scollan. 2009. Assessment of dietary ratios of red clover and grass silages on milk production and milk quality in dairy cows. J. Dairy Sci. 92:1148-1160. https://doi.org/10.3168/ jds.2008-1771.

Oba, M., and M. S. Allen. 2003. Effects of corn grain conservation method on ruminal digestion kinetics for lactating dairy cows at two dietary starch concentrations. J. Dairy Sci. 86:184-194. https: //doi.org/10.3168/jds.S0022-0302(03)73599-1.

Ørskov, E., and I. McDonald. 1979. The estimation of protein degradability in the rumen from incubation measurements weighted according to rate of passage. J. Agric. Sci. 92:499-503. https://doi .org/10.1017/S0021859600063048.

Plaizier, J. C., D. O. Krause, G. N. Gozho, and B. W. McBride. 2008. Subacute ruminal acidosis in dairy cows: The physiological causes, incidence and consequences. Vet. J. 176:21-31. https://doi.org/10 .1016/j.tvjl.2007.12.016.

Raffrenato, E., C. F. Nicholson, and M. E. Van Amburgh. 2019. Development of a mathematical model to predict pool sizes and rates of digestion of 2 pools of digestible neutral detergent fiber and an undigested neutral detergent fiber fraction within various forages. J. Dairy Sci. 102:351-364. https://doi.org/10.3168/jds.2018-15102.

Raffrenato, E., D. A. Ross, and M. E. Van Amburgh. 2018. Development of an in vitro method to determine rumen undigested aNDFom for use in feed evaluation. J. Dairy Sci. 101:9888-9900. https: //doi.org/10.3168/jds.2018-15101. 
Soteriades, A. D., A. M. Gonzalez-Mejia, D. Styles, A. Foskolos, J. M. Moorby, and J. M. Gibbons. 2018. Effects of high-sugar grasses and improved manure management on the environmental footprint of milk production at the farm level. J. Clean. Prod. 202:12411252. https://doi.org/10.1016/j.jclepro.2018.08.206.

Spek, J. W., J. Dijkstra, G. van Duinkerken, W. H. Hendriks, and A. Bannink. 2013. Prediction of urinary nitrogen and urinary urea nitrogen excretion by lactating dairy cattle in northwestern Europe and North America: A meta-analysis. J. Dairy Sci. 96:4310-4322. https://doi.org/10.3168/jds.2012-6265.

Thomas, A. T. 1977. An automated procedure for the determination of soluble carbohydrates in herbage. J. Sci. Food Agric. 28:639-642. https://doi.org/10.1002/jsfa.2740280711.

Urrutia, N. L., and K. J. Harvatine. 2017. Acetate dose-dependently stimulates milk fat synthesis in lactating dairy cows. J. Nutr. 147:763-769. https://doi.org/10.3945/jn.116.245001.

Van Amburgh, M. E., E. A. Collao-Saenz, R. J. Higgs, D. A. Ross, E. B. Recktenwald, E. Raffrenato, L. E. Chase, T. R. Overton, J. K. Mills, and A. Foskolos. 2015. The Cornell Net Carbohydrate and Protein System: Updates to the model and evaluation of version 6.5. J. Dairy Sci. 98:6361-6380. https://doi.org/10.3168/jds.2015 $-9378$
Van Soest, P. J. 1994. Nutritional Ecology of the Ruminant. Cornell University Press, Ithaca, NY.

Van Soest, P. J., J. B. Robertson, and B. A. Lewis. 1991. Methods for dietary fiber, neutral detergent fiber, and nonstarch polysaccharides in relation to animal nutrition. J. Dairy Sci. 74:3583-3597. https://doi.org/10.3168/jds.S0022-0302(91)78551-2.

Volden, H., and M. Larsen. 2011. Digestion and metabolism in the gastrointestinal tract. Pages 59-80 in NorFor-The Nordic Feed Evaluation System. H. Volden, ed. Wageningen Academic Publishers, Wageningen, the Netherlands.

Zhu, W.-Y., M. K. Theodorou, A. C. Longland, B. B. Nielsen, J. Dijkstra, and A. P. J. Trinci. 1996. Growth and survival of anaerobic fungi in batch and continuous-flow cultures. Anaerobe 2:29-37. https://doi.org/10.1006/anae.1996.0004.

\section{ORCIDS}

J. M. Moorby @ https://orcid.org/0000-0002-4449-8432

A. Foskolos ๑ https://orcid.org/0000-0002-7339-1140 